\title{
Predictive models of habitat preferences for the Eurasian eagle owl Bubo bubo: a multiscale approach
}

\author{
Jose Antonio Martínez, David Serrano and Iñigo Zuberogoitia
}

\begin{abstract}
Habitat preference of eagle owls Bubo bubo were examined through comparing habitat composition around 51 occupied cliffs and 36 non-occupied cliffs in Alicante (E Spain). We employed Generalized Linear Models to examine patterns of habitat preference at three different spatial scales: nest site $\left(7 \mathrm{~km}^{2}\right)$, home range $\left(25 \mathrm{~km}^{2}\right)$, and landscape $\left(100 \mathrm{~km}^{2}\right)$. At the nest site scale, occupied cliffs were more rugged, had a greater proportion of forest surface in the surroundings, and were further from the nearest paved road than unoccupied cliffs. Additionally, probability of having an occupied cliff increased when there was another occupied territory in the surroundings. At both the home range scale and the landscape scale, high probabilities of presence of eagle owls were related to high percentages of Mediterranean scrubland around the cliffs, which are the preferred habitat of European rabbits Oryctolagus cuniculus, the main prey of the owls. We suggest a hierarchical process of habitat selection in the eagle owl concerning suitable trophic resources at the broadest scales and adequate sites for breeding and roosting at the smallest scale. However, it should be noted that some structural features such as the proximity of roads were not necessarily avoided by the owls, but their presence were possibly constrained by systematic killing of individuals. Our paper provides new evidence for the requirement of multi-scale approaches to gain insight into both the different limiting factors for the persistence of populations and the role of individual perception of the environment in the evolution of habitat selection.
\end{abstract}

J. A. Martínez (qucocotiers@hotmail.com), C/Juan de la Cierua 43, El Campello, E-03560, Alicante, Spain. - D. Serrano, Dept of Applied Biology, Estación Biológica de Doñana (CSIC), Pabellón del Perú s/n, E-41013, Seuilla, Spain. - I. Zuberogoitia, Lab. Zoología, Dept de Zoología, Fac. de Ciencias, Uniu. del País Vasco, Aptdo 644, E-48080, Bilbao, Spain.

In recent decades, considerable attention has focused on determining the ways in which birds select the habitat from the different options available, usually by determining patterns of habitat preference for breeding sites (e.g. Belthoff and Ritchison 1990, Sieg and Becker 1990, Martínez et al. 1999), foraging areas (e.g. Redpath 1995, Rotenberry and Wiens 1998, Tella et al. 1998) or by assessing the influence of habitat composition on population density at the landscape level (e.g. Sánchez-Zapata and Calvo 1999, Carrete et al. 2000). However, habitat selection (i.e. the process involving behavioural decisions made by an animal about what habitat it would use) and habitat preference (i.e. the final pattern of habitat used with respect to its availability) have been usually confounded in the literature (Hall et al. 1997, Jones 2001). This distinction is important because while in some cases the current pattern of distribution may reflect accurately the process of selection involved, in others current habitat preference may not correspond completely with the distribution of suitable resources for the species (see Wiens 1989). Nonetheless, since habitat preference is at least in part a consequence of a past or ongoing process of habitat selection, it is often the only alternative to gain insight into habitat selection processes. 
On the other hand, studies considering multi-scale approaches to the study of habitat selection are still scarce (e.g. Kotliar and Wiens 1989, Sánchez-Zapata 1999, Hall and Mannan 1999, Penteriani et al. 2001a), although the choice of a suitable habitat is probably the result of the integration of different essential patches satisfying all the requirements of the individuals (Orians and Wittenberger 1991). The multi-scale approach to the study of habitat selection is mostly based on the conceptual framework suggested by Johnson (1980), whose basic assumption is that animals are capable of making decisions regarding resources (food, breeding sites) at consecutively smaller scales (see also Hutto 1985, Block and Brennan 1993). Therefore, general habitat selection may follow a spatially based hierarchy regarding, for example, a suitable patch for breeding at a small scale and appropriate areas for foraging at a broader scale. Because large birds usually need different patches for breeding and foraging and can fly long distances, multi-scale analyses may be specially useful to identify different key factors involved in habitat preference. In addition, a multi-scale approach allows one to identify relevant scales concerning individual perception of the landscape, otherwise difficult to select when a detailed knowledge of the behavioural ecology of the studied organism is not available. For this reason, in habitat preference studies the scale is usually arbitrarily set by researchers, or it is not justified (e.g. Bustamante 1997, Selås 1997, Penteriani and Faivre 1997, Mañ osa et al. 1998, Ontiveros 1999, SánchezZapata and Calvo 1999, Martínez et al. 1999), thus not fulfilling Johnson's rationale (1980).

The Eurasian eagle owl Bubo bubo is the largest nocturnal bird of prey inhabiting Eurasia. It is a top predator preying upon a wide range of animal species including several game-species such as the European rabbit Oryctolagus cuniculus in Mediterranean areas (Doná zar et al. 1989, Serrano 1998, 2000). Eagle owl populations have declined markedly in the last decades, although there have been widespread increases in its range of distribution in recent years (Tucker and Heath 1994). In Spain, small game management generates income for hunting states, and hunters claim that predators are responsible for reducing hunting bags. Thus, top predators are heavily persecuted in some areas. For instance, in Alicante (SE Spain) we recorded over 1000 birds of prey and owls as shooting casualties in the period between 1984 and 2000 (Martínez et al. 1996a, 2001) in spite of legal protection. Hunters frequently organise hunting parties to shoot Eurasian eagle owls, resulting in a minimum 201 casualties, mostly first to third calendar-year birds (Bermejo 2000). Since relationships between declining hunting bags and raptor persecution may also have a strong habitat component (Thirgood et al. 2000), managers will benefit from assessing the role of different environmental constrains that may influence the probability of settlement of top predators.
The aims of this study were: 1) to identify environmental features affecting habitat preference of breeding eagle owls at three different scales, i.e. nest site, home range, and landscape 2) to assess the relative contribution of these different variables at each scale in order to ascertain an individual bird's perception of the environment, and 3) to infer how the observed pattern of habitat preference reflect the decision-making process of individual choice in our study area.

\section{Methods}

\section{Study area}

The study area covered over of the province of Alicante (3200 $\mathrm{km}^{2}$ between $38^{\circ} 40^{\prime}-38^{\circ} 00^{\prime} \mathrm{N}$ and $1^{\circ} 00^{\prime}-0^{\circ} 00^{\prime} \mathrm{W}$ ). The climate slightly varies from semi-arid meso-Mediterranean in the south to sub-humid Mediterranean towards the north. Average annual rainfall is ca 400 $\mathrm{mm}$, and annual average temperature is ca $19^{\circ} \mathrm{C}$. The northern part of the province is rugged, dominated by dry cultivated fields, mainly almond Prunus amygdalus and olive trees Olea europaea, scrubland and small Aleppo pine Pinus halepensis forests. The south is much less rugged, and landscape is dominated by dry and irrigated fields, mainly vineyards and citrics, and scrubland.

\section{Censuses}

We located Eurasian eagle owls every year from October to July between 1995 and 1999 using a variety of methods: listening to spontaneous vocalisations, listening to begging nestlings, and walking ridges looking for nests and food remains. Every territory was visited at a minimum of four times at different stages of the breeding cycle to ascertain if they were consistently occupied (Olsson 1997). In order to study spatial distribution patterns we used the additive survey method (Newton 1991). For our analysis, habitat composition around 51 occupied cliffs was compared with that of 36 non-occupied but apparently suitable cliffs.

\section{Selection of scales and variables}

A cliff was considered as suitable for nesting when there were suitable cavities and it was higher than $4 \mathrm{~m}$ according to general preferences of eagle owls in the study area (unpubl.). Under this conservative criterion, cliff availability is high in the study area, and cliffs are distributed almost contiguously over the landscape (Anon. 1997).

We used three different scales to study habitat use of eagle owls: a) Nest site scale (7 $\mathrm{km}^{2}$ around the cliffs). 
This area was chosen because $92 \%$ of the observations $(n=225)$ of hooting eagle owls a few weeks before laying were encompassed by a circle of $1.5 \mathrm{~km}$ radius around the points where owls were frequently heard (hereafter, centres of activity). Furthermore, all of the 16 nests found in this study were located within this radius, as well as most of the plucking and roosting places. Although the owls can hoot several kilometres away from the nests (Ruiz-Martínez et al. 1996), the frequency of use of perches from which owls hooted was a good estimator of the location of the nests. Thus, the $7 \mathrm{~km}^{2}$ areas around centres of activity are likely to represent the nesting habitats in the study area. b) Home range scale ( $25 \mathrm{~km}^{2}$ around the cliffs). It has been suggested that eagle owls hunt mainly in areas of 10-20 km² (Haller 1978, Mikkola 1983), although telemetry studies showed that their territories may be larger (Dalbeck et al. 1998). Thus, we conservatively assumed home ranges to be $25 \mathrm{~km}^{2}$ (radius of $2.8 \mathrm{~km}$ around the centre of activity). c) Landscape scale (100 $\mathrm{km}^{2}$ around the cliffs). Since landscape ecology addresses the relationships between animal distribution and mosaics of ecosystems (Forman and Gordon 1986), we tested for a possible response of the owls to habitat composition at a larger landscape level (Sánchez-Zapata and Calvo 1999). Thus, we chose a radius of $5.6 \mathrm{~km}$ around centres of activity because in Alicante it is likely to find substantial changes in landscape composition within this radius from the cliffs used by eagle owls (Anon. 1997).

We selected 19 environmental variables related to topography, human influence and land use (Appendix $1)$. These variables were used because they can potentially influence the presence and abundance of eagle owls (Doná zar 1988, Sánchez-Zapata 1999, Martínez and Calvo 2000). Notice that the presence of another territory within the selected radius at each scale was included in the analyses to test whether some kind of conspecific interaction is influencing the presence of the species.

\section{Analytical procedures}

We used Generalised Linear Models (GLMs, McCullagh and Nelder 1989) to obtain a mathematical description of habitat selection by owls in an attempt to avoid covariance of explanatory variables. GLMs allow for the use of appropriate error formulations from the exponential family distributions avoiding restrictions of traditional regression models. A Generalised Linear Model consists of the following components: a linear predictor, an error function and a link function. The linear predictor (LP) is defined as:

$\mathrm{LP}=\mathrm{a}+\mathrm{bx}_{1}+\mathrm{cx}_{2}+\cdots$ where $\mathrm{a}$ is the intercept, $\mathrm{b}, \mathrm{c} \ldots$ are the parameter estimates to be obtained from the observed data, and $\mathrm{x}_{1}, \mathrm{x}_{2}, \ldots$ are the explanatory variables. The error and link functions depend on the nature of the data. We conducted three separate GLMs for the environmental description of data. Since the presence of eagle owls (a binary response variable: $1=$ presence, $0=$ absence) follows a binomial distribution, a logit link function was used (e.g. Doná zar et al. 1993, Bustamante 1997). Each explanatory variable and all possible interactions were fitted to the observations using the GENMOD procedure of SAS package (Anon. 1996). Each variable was tested for significance in turn, retaining those that contributed to the largest significant change in deviance. Only those variables significant at the $1 \%$ level were included in the models (Nicholls 1989). Quadratic and cubic functions were also tested to ensure that a higher order polynomial did not improve the models. We corrected for overdispersion when necessary. The best models were selected by likelihood ratio tests for type I analysis (Anon. 1996). Finally, Kappa statistics (Titus et al. 1984) allowed us to test whether model discrimination significantly improved chance classifications.

\section{Results}

\section{Habitat preference at the $7 \mathbf{k m}^{2}$ scale}

The habitat model at this spatial scale explained 57.2\% of the original deviance (Fig. 1). This model showed that the probability of finding an occupied cliff increased with irregular topography and with the amount of forest cover, while it decreased with the extent of paved roads around the cliffs (Table 1). Additionally, it showed that this probability increased when there was another occupied cliff within the $1.5 \mathrm{~km}$ radius. This model classified correctly $88.2 \%$ of the occupied cliffs and $91.7 \%$ of the unoccupied cliffs. This classification was $79.9 \%$ better than chance (Kappa test, $Z=7.23$, $\mathrm{p}<0.0001$ ). Relief was the most important variable at this scale, accounting for $49.1 \%$ of the explained deviance (Fig. 1). It alone classified correctly $100 \%$ of occupied cliffs, but only $27.8 \%$ of the sites where eagle owls were absent.

\section{Habitat preference at the $25 \mathbf{~ k m}^{2}$ scale}

The probability of having an occupied cliff at this scale accounted for $91.7 \%$ of the original deviance (Fig. 1). This model predicted high probabilities of presence of owls in cliffs with high percentages of surface covered by scrubland around them and situated at higher minimum altitudes above sea level (Table 2). This second model classified correctly $97.2 \%$ of occupied cliffs and 


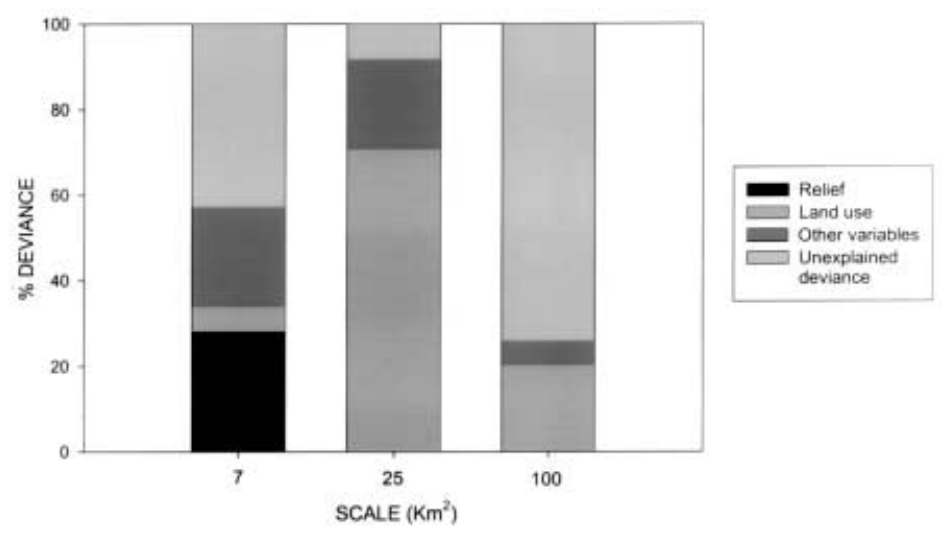

Fig. 1. Percentage of deviance explained at three spatial scales $\left(7,25\right.$ and $\left.100 \mathrm{~km}^{2}\right)$ by the Generalized Linear Models.

Table 1. Generalized Linear Model (GLM) for probability of presence of Eurasian eagle owls at the $7 \mathrm{~km}^{2}$ scale, using binomial error and logistic link.

\begin{tabular}{|c|c|c|c|c|}
\hline Parameter & Estimate & Standard error & $z^{2}$ & $\mathrm{p}$ \\
\hline Intercept & 26.3320 & 0.8600 & & \\
\hline Relief & 0.0816 & 0.0196 & 53.86 & 0.0001 \\
\hline Metres of paved roads & -0.0005 & 0.0001 & 25.06 & 0.0001 \\
\hline Neighbours & 27.7056 & 0.0000 & 19.59 & 0.0001 \\
\hline Forest & 0.0541 & 0.0207 & 11.28 & 0.0008 \\
\hline Residual deviance & 50.4540 & & & \\
\hline
\end{tabular}

Table 2. Generalized Linear Model (GLM) for probability of presence of Eurasian eagle owls at the $25 \mathrm{~km}^{2}$ scale, using binomial error and logistic link.

\begin{tabular}{|c|c|c|c|c|}
\hline Parameter & Estimate & Standard error & $z^{2}$ & $\mathrm{p}$ \\
\hline Intercept & -11.0226 & 1.6739 & & \\
\hline Scrubland & 0.1579 & 0.0235 & 714.44 & 0.0001 \\
\hline Minimum altitude above sea level & 0.0648 & 0.0105 & 210.93 & 0.0001 \\
\hline Residual deviance & 9.8206 & & & \\
\hline
\end{tabular}

98.0\% of unoccupied cliffs, this classification being 95.3\% better than chance (Kappa test, $\mathrm{Z}=8.62, \mathrm{p}<$ 0.0001 ). Scrubland alone accounted for $77.2 \%$ of the explained deviance at this scale.

\section{Habitat preference at the $100 \mathrm{~km}^{2}$ scale}

For this scale, we obtained a model accounting for $25.97 \%$ of the original deviance (Fig. 1). Two explanatory variables entered significantly into this GLM, again predicting high probabilities of presence of eagle owls in cliffs with high percentages of scrubland cover, and at low minimum altitudes above sea level (Table 3).
The GLM at this scale correctly classified $88.2 \%$ of occupied cliffs and $83.3 \%$ of unoccupied cliffs, this classification being $71.5 \%$ better than chance (Kappa test, $\mathrm{Z}=6.48, \mathrm{p}<0.0001$ ).

\section{Discussion}

Distribution of raptors may be the result of a wide set of interacting variables (e.g. Potapov 1997), therefore some caution is needed when establishing causal relationships between bird distribution and habitat variables selected on statistical grounds (Austin et al. 1996).

Table 3. Generalized Linear Model (GLM) for probability of presence of Eurasian eagle owls at the $100 \mathrm{~km}^{2}$ scale, using binomial error and logistic link.

\begin{tabular}{lrrr}
\hline Parameter & Estimate & Standard error & $z^{2}$ \\
\hline Intercept & -1.1616 & 0.5091 & 0.0001 \\
Scrubland & 0.0645 & 0.0149 & 24.05 \\
Minimum altitude above sea level & -0.0032 & 0.0013 & 6.60 \\
Residual deviance & 87.3602 & & 0.0102 \\
\hline
\end{tabular}


However, our models including habitat features at three scales were good predictors of Eurasian eagle owls' presence in our study area, suggesting that the pattern of habitat preference results from a scale-dependent habitat selection process.

The model at the $7 \mathrm{~km}^{2}$ scale shows that the owls used nesting areas based mainly on topographic irregularity, as previously stated in other Mediterranean areas (Doná zar 1988, Sánchez-Zapata 1999, Penteriani et al. 2001b). Cliffs may provide suitable cavities for nesting and dominant points from where to effectively proclaim territory ownership. Rugged areas probably facilitate the use of slope winds by the owls, and more alternative roosts and nest sites might be also available. Accordingly, we recorded 156 observations of owls departing just before dusk and in windless days, $70 \%$ of which corresponded to owls gliding for distances up to $1 \mathrm{~km}$, probably taking benefit of their low wing load (Norberg 1987). Additionally, occupied cliffs were placed in areas with lower human disturbance than unoccupied cliffs, in agreement with studies of breeding habitat preference on other raptors (e.g. Sergio and Bogliani 1999, Martínez et al. 1999, Suárez et al. 2000). In fact, the power of prediction of the variable "relief" alone is strong for occupied cliffs, but notably decreases for unoccupied cliffs predicted to be occupied by their topographic features. This suggests that human disturbance is a constraint for the settlement of the owls in adequate areas as expressed in terms of topographic irregularity. Compared to other large raptors, eagle owls have been said to be fairly tolerant to human-related environmental alterations but to be sensitive to direct human persecution (Doná zar 1988). Thus, our results probably indicate that they persist in safe breeding places free of systematic killing of adults, which has been reported as the main cause of mortality in this species in the study area (Martínez et al. 1996a). This constitutes a good example of the difference between habitat preference and habitat availability, since our models seem to reflect factors constraining the persistence of the owls rather than an active avoidance of a given structural feature. Furthermore, the detected preference for more rugged areas do not necessarily indicate a selection process, but could be also reflecting high levels of direct human pressure in less rugged, more accessible localities (Sánchez-Zapata et al. 1995).

The probability of presence of the owls was positively related to the presence of other territory at this scale of investigation. Clustering of territorial animals could be explained in two, non-exclusive ways. First, aggregation of breeding territories could result from the clumped distribution of suitable cliffs for breeding, i.e. those more rugged with low levels of human disturbance (Doná zar 1987). Second, eagle owls may be cuing on local environmental quality by the presence of conspecifics, as useful way to assess habitat suitability indirectly (Stamps 1991, Muller et al. 1997, Serrano et al.
2001). Independently of how individuals gather information on potential breeding patches, high breeding densities, and therefore tolerance to close neighbours, have been previously detected in this territorial species (Penteriani et al. 2001b).

The variables "scrubland" and "minimum altitude above sea level" were the best predictors of eagle owl presence at both the 25 and the $100 \mathrm{~km}^{2}$ scales (Tables 2 and 3). Nonetheless, the GLM obtained for the foraging home range of $25 \mathrm{~km}^{2}$ was noticeably better than the model built at the landscape scale of $100 \mathrm{~km}^{2}$ (Fig. 1). Eagle owls preferred areas with high elevation above sea level at the $25 \mathrm{~km}^{2}$ scale, while this variable entered into the model with an opposite trend at the $100 \mathrm{~km}^{2}$ scale. Since the majority of the occupied territories were located far from littoral areas, where most of the human population concentrates, the direct relationship between the presence of occupied cliffs and altitude within the available range of altitude probably indicates a preference of the eagle owl for areas where scrubland is the main land cover (Rigual-Margalló 1984), as well as avoidance of largely disturbed areas not detected by our GLMs. At the broader $100 \mathrm{~km}^{2}$ eagle owls preferred low minimum altitudes, which are probably associated with Mediterranean areas at the landscape level. Although "scrubland" is a broad habitat classification (Rigual-Margalló 1984), both scrubland and minimum altitude are probably indicating selection of Mediterranean ecosystems with low bushes. Mediterranean scrubland is the preferred habitat of European rabbits (Moreno and Villafuerte 1995), which were the main prey of the owls in the study area (Martínez et al. 1996b). This finding agrees with other studies focused on habitat preference of raptors feeding on rabbits (e.g. Gonzá lez et al. 1990), and seems to indicate that the presence of eagle owls is determined by the presence of the most profitable prey at this scale.

It should be noted that the relative preference of each habitat at the two broadest scales is substantially similar. It has been suggested that the relative importance of each environmental limiting factor could be related to the scale of selection, with more important factors driving preferences at the broadest scales (Rettie and Messier 2000). Accordingly, our results showing that selection of Mediterranean scrubland persists over the two broad scales suggests that eagle owls' distribution in our study area is mainly governed by the distribution of high profitable prey, until a threshold at which the owls focus their selection on other activities such as breeding site choice at a smaller scale. For instance, our model at the nest site scale detected that the probability of occupancy of a cliff increased with the amount of forest cover, contrary to previous studies indicating a strong relationship between eagle owl presence and the amount of open areas (e.g. Blondel and Badan 1976, Cheylan 1979, Penteriani et al. 2001b), and to the results obtained in this study at the home range and 
landscape levels. This finding seems to indicate that the search image of eagle owls at the smallest spatial scale does not concentrate on habitat features related to food supply, probably because other elements related to breeding and roosting requirements (e.g. rugged areas) play a much more important role. Thus, the process of habitat selection of Eurasian eagle owls might occur as follows: initially, individuals assess general habitat features at the level of the landscape (Svärdson 1949, Hildén 1965) that may be determined by the existence of good foraging areas. Then, Eurasian eagle owls would respond to more specific attributes of the habitat in determining where to settle, namely an area with enough trophic resources with a centre of activity characterised by rugged relief adequate for breeding and roosting.

Eagle owls have been said to be linked to good hunting areas near the nest site (Doná zar 1988, Sánchez-Zapata 1999, Penteriani et al. 2001b), and to forage mainly in a $2 \mathrm{~km}$ radius around nests (Haller 1978). Nonetheless, our finding that habitats preferred by rabbits were not included in the model for $7 \mathrm{~km}^{2}$ around the cliffs may not support the hypothesis that Eurasian eagle owls hunt necessarily in the vicinity of the nests. A stronger relationship between Eurasian eagle owls and structural features that are good estimators of rabbit presence emerged at the home range scale. This finding is supported by the results of a telemetry study by Dalbeck et al. (1998), who found that Eurasian eagle owls visited frequently patches far from their nests, and by the results of Rohner (1998) with the closely related great horned owl Bubo uirginianus, who also reported that owls were attracted to experimental patches of high prey abundance far from the nests. Indeed, in our study area rabbit populations have dropped dramatically as a consequence of viral diseases and human hunting pressure (Martínez and Zuberogoitia 2001). Therefore, the pattern of habitat preference observed in our study area could be the result of long-term changes in rabbit abundance that could have forced Eurasian eagle owls to increase hunting ranges by visiting good patches over a larger area.

In conclusion, we obtained the best models for habitat preference at the two smallest scales. Eagle owls seem to use undisturbed rugged areas at the breeding requirements scale, while they used habitat patches reflecting more accurately food supply at the broadest levels. Thus, the factors influencing the place where large raptors settle could involve at least two primordial scales with respect to nest site and foraging. Our study provides new evidence for the requirement of different spatial-scale analyses to understand population limitations arising from the complexity of ecological processes imposed by multi-scale constrains. A multi-scale approach may hence improve our understanding of suitability and carrying capacity of the environment, and thus the individual's perception of ecological pressures under which habitat selection has evolved.

Acknowledgements - We are most indebted to F. Falcó, HELIACA, A. Izquierdo, J. Izquierdo, L. Rico, Fran, P. Cantó, D. M. J. Payá, T. Zaragozí, L. Fidel, A. Gracia, P. Segarra, A. Saez and to the C. R de Santa Faç for their invaluable help over the years. V. Penteriani, J. L. Tella, R. Jovani, J. A. Doná zar, D. Sol, C. Rohner, E. Barba, L. Dalbeck and M. Mönkkönen made useful comments on a previous version of the manuscript.

\section{References}

Anon. 1996. SAS/STAT software: changes and enhancements through release 6.11. - SAS Inst.

Anon. 1997. Mapa geocientífico de la Provincia de Alicante. Generalitat Valenciana. Valéncia.

Austin, E. G. et al. 1996. Predicting the spatial distribution of buzzard Buteo buteo nesting areas using a Geographical Information System and remote sensing. - J. Appl. Ecol. 33: $1451-1550$.

Belthoff, J. R. and Ritchison, G. 1990. Nest-site selection by eastern screech owls in central Kentucky. - Condor 92: 982-990.

Bermejo, S. 2000. Memoria de Caza del Coto de Agua Amarga 1990-2000. - Soc. de Caza de Agua Amarga, Alicante.

Block, W. M. and Brennan, L. A. 1993. The habitat concept in ornithology. Theory and applications. - In: Power, D. M. (ed.), Current ornithology 11. Plenum Press, pp. 35-91.

Blondel, J. and Badan, O. 1976. La biologie du Hibou Grandduc en Provence. - Nos Oiseaux 33: 189-219.

Bustamante, J. 1997. Predictive models for lesser kestrel Falco naumanni distribution, abundance and extinction in southern Spain. - Biol. Conserv. 80: 153-160.

Carrete, M., Sánchez-Zapata, J. A. and Calvo, J. F. 2000. Breeding densities and habitat attributes of golden eagles in south-eastern Spain. - J. Raptor Res. 34: 48-52.

Cheylan, G. 1979. Reserches sur l'organisation du peuplement de vertebrés d'une montagne mediterranéenne. - Ph.D. thesis, Univ. Pierre et Marie Curie, Paris.

Dalbeck, L., Bergerhausen, W. and Krishner, O. 1998. Telemetriestudie zur Orts- und Partnertreue beim Uhu Bubo bubo. - Vogelwelt 119: 37-344.

Doná zar, J. A. 1987. Espaciamiento y dispersion de nidos de Búho Real Bubo bubo en Navarra (Norte de la Península Ibérica). - Munibe 40: 35-58.

Doná zar, J. A. 1988. Selección de hábitat de nidificación por el Búho Real (Bubo bubo) en Navarra. - Ardeola 35: 233245.

Doná zar, J. A. et al. 1989. Comparative food habits of the Eurasian eagle owl Bubo bubo and the great horned owl Bubo uirginianus in six Paleartic and Neartic biomes. Ornis Scand. 20: 298-306.

Doná zar, J. A., Hiraldo, F. and Bustamante, J. 1993. Factors influencing nest-site selection, breeding density and breeding success in the bearded vulture (Gypaetus barbatus). - J. Appl. Ecol. 30: 504-514.

Forman, R. T. and Gordon, M. 1986. Landscape ecology. John Wiley.

Gonzá lez, L. M., Bustamante, J. and Hiraldo, F. 1990. Factors influencing the present distribution of the Spanish imperial eagle Aquila adalberti. - Biol. Conserv. 51: 311319.

Hall, L. S. and Mannan, R. W. 1999. Multi-scaled habitat selection by elegant trogons in southeastern Arizona. - J. Wildl. Manage. 63: 451-461.

Hall, L. S., Krausman, P. R. and Morrison, M. L. 1997. The habitat concept and a plea for standard terminology. Wildlife Soc. Bull. 25: 173-182. 
Haller, H. 1978. Zur Populationsökologie des Uhus Bubo bubo in Hochgrebige: Bestand, Bestandesenttwickland und Lebenstaum in den Rätischen alpen. - Orn. Beob. 75: 237-365.

Hildén, O. 1965. Habitat selection in birds. - Ann. Zool. Fenn. 2: $53-75$.

Hutto, R. L. 1985. Habitat selection by nonbreeding, migratory land birds. - In: Cody, M. L. (ed.), Habitat selection in birds. Academic Press, pp. 455-476.

Johnson, D. H. 1980. The comparison of usage and availability measurements for evaluating resource preference. Ecology 61: 65-71.

Jones, J. 2001. Habitat selection studies in avian ecology: a critical review. - Auk 118: 557-562.

Kotliar, N. B. and Wiens, J. A. 1989. Multiple scales in patchiness and patch structure: a hierarchical framework for the study of heterogeneity. - Oikos 59: 253-260.

Mañ osa, S., Real, J. and Codina, J. 1998. Selection of settlement areas by juvenile Bonelli's eagle in Catalonia. - J. Raptor Res. 32: 208-214.

Martínez, J. A. and Zuberogoitia, I. 2001. The response of the eagle owl (Bubo bubo) to an outbreak of the rabbit haemorrhagic disease. - J. Ornithol. 142: 204-211.

Martínez, J. A. et al. 1996a. Causas de mortalidad de las rapaces nocturnas en la Comunidad Valenciana. - Quercus 126: $18-19$.

Martínez, J. A. et al. 1996b. Distribució n y dieta del Búho Real en la provincia de Alicante. - Quercus 126: 20.

Martínez, J. A. et al. 1999. Hábitat de caza y nidificación del Aguilucho Cenizo en el Parque Natural de la Mata-Torrevieja (Alicante, SE de España): efectos de la estructura de la vegetación y de la densidad de presas. - Ardeola 46: 205-212.

Martínez, J. A., Izquierdo, I. and Zuberogoitia, I. 2001 Causes of admission of raptors in rescue centres of the east of Spain and proximate causes of mortality. - Biota 2: 163-169.

Martínez, J. E. and Calvo, J. F. 2000. Selección de hábitat de nidificación por el búho real Bubo bubo en ambientes mediterrá neos semiáridos. - Ardeola 47: 215-220.

McCullagh, P. and Nelder, J. A. 1989. Generalised Linear Modelling. - Chapman and Hall.

Mikkola, H. 1983. Owls of Europe. - Poyser.

Moreno, S. and Villafuerte, R. 1995. Traditional management of scrubland for the conservation of rabbits and their predators in Doñ ana National park, Spain. - Biol. Conserv. 73: 81-85.

Muller, K. L. et al. 1997. The effects of conespecifics attraction and habitat quality on habitat selection in territorial birds (Troglodytes aedon). - Am. Nat. 150: 650-661.

Newton, I. 1991. Habitat variation and population regulation in sparrowhawks. - Ibis 133: 76-88.

Nicholls, A. O. 1989. How to make biological surveys go further with generalised linear models. - Biol. Conserv. 50: $51-75$.

Norberg, R. 1987. Evolution, structure and ecology of northern forest owls. - In: Anon. (ed.), Biology and conservation of northern forest owls. For. Serv. Gen. Tech. Rep., pp. 9-43.

Olsson, V. 1997. Breeding success, dispersal, and long-term changes in a population of Eurasian eagle owls Bubo bubo in southeastern Sweden 1952-1996. - Ornis Svecica 7: 49-60.

Ontiveros, D. 1999. Selection of nest cliffs by Bonelli's eagle (Hieraaetus fasciatus) in southern Spain. - J. Raptor Res. 33: $110-116$.

Orians, G. H. and Wittenberger, J. F. 1991. Spatial and temporal scales in habitat selection. - Am. Nat. 137: 29-49.

Penteriani, V. and Faivre, B. 1997. Breeding density and landscape-level habitat selection of common buzzard $(\mathrm{Bu}$ teo buteo) in a mountain area (Abruzzo Apennines, Italy). - J. Raptor Res. 31: 208-212.
Penteriani, V., Faivre, B. and Frochot, B. 2001a. An approach to identify factors and levels of nesting habitat selection: a cross-scale analysis of goshawk preferences. - Ornis Fenn. 78: 159-167.

Penteriani, V. et al. 2001b. Effects of landscape spatial structure and composition on the settlement of the Eurasian eagle owl Bubo bubo in a Mediterranean habitat. - Ardea 89: 331-340.

Potapov, E. R. 1997. What determines the population density and reproductive success of rough-legged buzzards Buteo lagopus in the Siberian tundra? - Oikos 78: 362-376.

Redpath, S. M. 1995. Habitat fragmentation and the individual: tawny owl Strix aluco in woodland patches. - J. Anim. Ecol. 64: 652-661.

Rettie, W. J. and Messier, F. 2000. Hierarchical habitat selection by woodland caribou: its relationship to limiting factors. - Ecography 23: 466-478.

Rigual-Margalló, A. 1984. Flora y Vegetación de la Provincia de Alicante. - Inst. de Estudios Juan Gil-Albert. Diputación Provincial de Alicante.

Rohner, C. 1998. Response of great horned owls to experimental "hot spots" of snowshoe hare density. - Auk 115: 694-705.

Rotenberry, J. T. and Wiens, J. A. 1998. The evolution of coloniality in birds in relation to food, predation, and life-history traits: a comparative analysis. - Am. Nat. 151: 514-529.

Ruiz-Martínez, I., Hodar, J. A. and Camacho, I. 1996. Cantonnement et comportement vocal du Grand-Duc d'Europe Bubo bubo dans les monts de la Sierra Morena (Sud de l'Espagne). - Alauda 64: 345-353.

Sánchez-Zapata, J. A. 1999. Las aves rapaces y su relación con la estructura del paisaje en ambientes mediterrá neos semiáridos. - Ph.D. thesis, Univ. of Murcia.

Sánchez-Zapata, J. A. and Calvo, J. F. 1999. Raptor distribution in relation to landscape composition in semi-arid Mediterranean habitats. - J. Appl. Ecol. 36: 245-262.

Sánchez-Zapata, J. A. et al. 1995. Ecología de las Aves de Presa de la Región de Murcia. - Univ. de Murcia.

Selås, V. 1997. Influence of prey availability on re-establishment of goshawk Accipiter gentilis nesting territories. Ornis Fenn. 74: 113-120.

Sergio, F. and Bogliani, G. 1999. Eurasian hobby density, nest area occupancy, diet, and productivity in relation to intensive agriculture. - Condor 101: 806-817.

Serrano, D. 1998. Diferencias interhá bitat en la alimentació n del Búho Real (Bubo bubo) en el valle medio del Ebro (NE de Españ a): efecto de la disponibilidad de conejo (Orycto lagus cuniculus). - Ardeola 45: 47-53.

Serrano, D. 2000. Relationship between raptors and rabbits in the diet of eagle owls in southwestern Europe: competition removal or food stress? - J. Raptor Res. 34: 305-310.

Serrano, D. et al. 2001. Factors affecting breeding dispersal in the facultatively colonial lesser kestrel: individual experience vs. conspecific cues. - J. Anim. Ecol. 70: 568-578.

Sieg, H. C. and Becker, D. M. 1990. Nest-site habitat selection by merlins in southeastern Montana. - Condor 92: 688694.

Stamps, J. A. 1991. The effect of conspecifics on habitat selection in territorial species. - Behav. Ecol. Sociobiol. 28: 29-36.

Suárez, S., Balbontín, J. and Ferrer, M. 2000. Nesting habitat selection by booted eagles Hieraaetus pennatus and implications for management. - J. Appl. Ecol. 37: 215-223.

Svärdson, G. 1949. Competition and habitat selection in birds. - Oikos 1: 157-174.

Tella, J. L. et al. 1998. Conflicts between lesser kestrel conservation and European agricultural policies as identified by habitat use analysis. - Conserv. Biol. 12: 593-604.

Thirgood, S. J. et al. 2000. Habitat loss and raptor predation: disentangling long- and short-term causes of red grouse declines. - Proc. R. Soc. Lond. B 267: 651-656. 
Titus, K. Mosher, J. A and Williams, B. K. 1984. Chance corrected classification for use in discriminant analysis and ecological applications. - Am. Midl. Nat. 111: 1-7.

Tucker, G. M. and Heath, M. F. 1994. Birds in Europe: their conservation status. - BirdLife Conservation Series, no. 3. - BirdLife Int.

Wiens, J. A. 1989. The ecology of bird communities. Vol. 1. Foundations and patterns. - Cambridge Stud. in Ecol.

Appendix 1. Variables used to characterize centres of activity at the 7,25 and $100 \mathrm{~km}^{2}$ scales.

\section{Physiography}

Relief, measured as the number of $100 \mathrm{~m}$ contours cut

by four lines starting from the centre of the area in

directions $\mathrm{N}, \mathrm{S}, \mathrm{E}$ and $\mathrm{W}$.

Maximum altitude, above sea level.

Minimum altitude, above sea level.

Average altitude, (maximum altitude + minimum altitude)/2.
Altitudinal difference, maximum altitude-minimum altitude.

Human disturbance

Unpaved roads, metres around the cliff.

Paved roads, metres around the cliff.

Distance to nearest unpaved road, in metres.

Distance to nearest paved road, in metres.

Distance to the nearest building, in metres.

Number of buildings.

Land use (\%)

Forest

Scrubland

Non-irrigated cultures

Irrigated cultures

Non-cultivated lands

Salt marshes

Gravel pits

Water

Presence of conspecifics

Neighbours, presence (1) or absence (0) of other occupied cliff in the circular sampling area. 